\title{
СТУПАЫЕ У ЦРКВУ ПРЕМА КАТИХЕТСКИМ ОМИЛИЈАМА ТЕОДОРА МОПСУЕСТИЈСКОГ
}

\begin{abstract}
Резиме

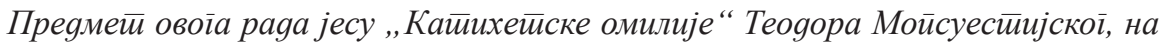

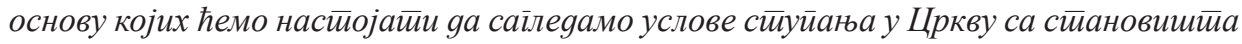
исииоријско - иравне иерсиеекииве. Теоgор Мойсуестиијски важи за јеgної оg најкре-

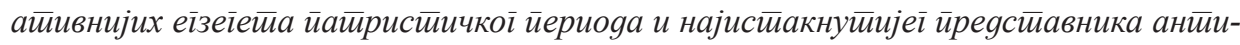

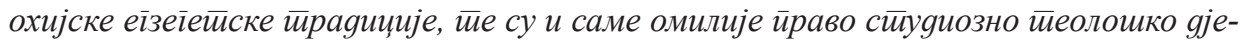
ло, иако су сииваране у живом іовору, ијј. у ирисном gоgиру са кайихуменима којима се он обраћао. Дефинишући сакременй као оно шито указује на невияљиве и не-

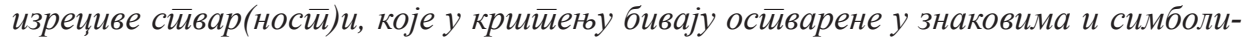

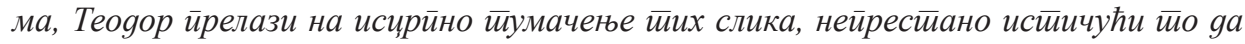

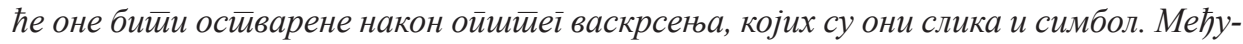

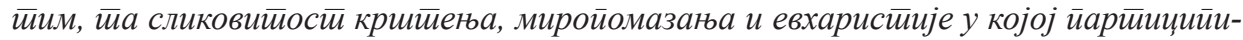
рамо никако не умањује юихову реалносй, ийавише, већма је найлашава и исииче.

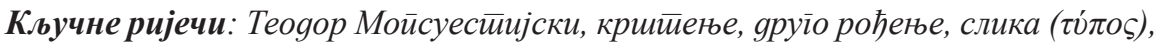

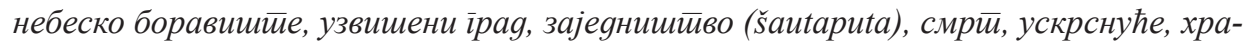
на бесмрииностии.
\end{abstract}

\section{Увод}

Црква, као што знамо, не прима своје чланове у њено окриље на основу пуке изјаве појединца да жели у њу да ступи, будући да она не представља само заједницу људи који су обједињени истом вјером. ${ }^{1}$ Црква је народ Божији ${ }^{2}$,

1 То је јасно и из Златоустових ријечи, који каже да је Христиос из својих ребара сазgао Цркву, као шито је и Еву сазgао из Аgамової ребра, тако што је из његових животворних ребара на крсту прво потекла вода као симбол крштења, а потом крв као симбол страшних светих тајни. Тако, будући да се Црква из тога двога родила - бањом новоїа рођења и обновљеља Духом Свешим (Тит 3, 5), то јест крштењем и светим Тајнама - онда се у њу може ступити и једино кроз то двоје (уп. Свети Јован Златоусти, Кайихезе, Београд 2008, III, 17, 42).

2 Теодор, осврћући се на Спаситељеве ријечи у Мт 16, 18 - 19, назива Цркву и сли-

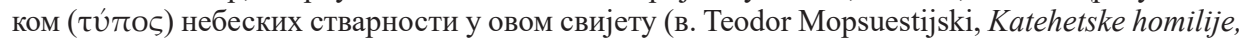
Zagreb 2004, 12, 11, 109). 
народ који је Бог образовао за себе и са којим је склопио савез ${ }^{3}$ на Голготи, народ Богом сабран у тијелу Христовом. У том смислу, ступање у Цркву јесте ступање у тијело Христово, како и пише апостол Павле: „Јер се и једним Духом сви ми крстисмо у једно тијело“ (1Кор 12,13$).{ }^{4}$ Као ново рођење и рођење ogoзй (уп. Јн 3, 3-8), ступање у Цркву представља креативни чин, који се савршава Духом, и зато онај који ступа у Цркву постаје нова твар у Христу (уп. 2Кор $5,17)$. Човјек духовно рођен у крштењу водом и Духом ступа у тијело Христово, у нови живот, и постаје уд народа Божијег ${ }^{5}$, као што и говори Теодор Мопсуестијски:

„Jedna jedina je Bit (ituta), bez tijela i granica, Oca i Sina i Duha Svetoga, i ona nam u krštenju daje posinjenje ${ }^{6}$, (ono) u koje mi vjerujemo, u koje se krstimo i po kojem postajemo jedno tijelo po djelovanju (maebdanuta) koje, u krštenju, u nama izvodi Duh Sveti. Po tom (djelovanju) mi postajemo sinovi Božji i jedno tijelo našega Gospodina Krista..." 7

Период након Миланског едикта представља вријеме процвата катихумената, и то у његовом пуном облику. У знатно измијењеним просторним околностима, вријеме савршавања свете тајне хришћанске иницијације у овом периоду прилагођава се новом устројавању литургијског времена. То ново устројавање литургијског времена које је, услед посве другачијих околности живота хришћана, у центар годишњег богослужбеног круга поставило годишње празновање Пасхе ${ }^{8}$, условило је да се и сама катихизација

3 О том савезу Теодор, између осталог, каже следеће: „....savez je to što ga (Bog) sklopi s ljudskim rodom [ $\gamma$ ćvos] »ekonomijom « našega Gospodina Isusa Krista, ukidajući sve druge stare stvari i na njihova mjesta pokaza nove. ... Nestala je smrt i propadljivost, gotovo je sa strastima i promjenljivošću. ... nove stvari namjesto starih, nepokvarljive i besmrtne namjesto smrtnih i pokvarljivih..." (Teodor Mopsuestijski, нав. gјело, 1, 3, 2).

4 Овај стих је у непосредној вези са оним који је Павле већ нешто раније изрекао у 1 Кор 10, 17: „Јер један је хљеб, једно смо тијело многи, пошто се сви од једнога хљеба причешћујемо“. Што ће рећи: крштени смо у једно тијело - Господа Исуса Христа, и са Њим постајемо једно тијело - причешћујући се Њиме. Као што ћемо видјети, то је оно што и сам Теодор истиче у свом обраћању новокрштенима.

5 в. Николај Афанасјев, Сйуйање у Цркву, Краљево 2008, 15-16. Тако Теодор истиче: „Mi očekujemo da imamo zajedništvo (šautaputa) s njime; i (već) odsada on nas otima životu ovoga svijeta i čini da umremo svijetu i Zakonu, jer Zakon ima moć nad svijetom, dok smo mi, prema slici

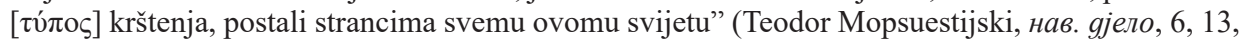
49). Интересантно је да Теодор користи исти овај израз šautaputa када говори и о тјелесном општењу мушкарца и жене (уп. Teodor Mopsuestijski, нав. gјело, 2, 6, 12).

6 „Нека нико не мисли да је ово крштење само благодат опроштаја грехова као што је Јованово крштење било: ово крштење је и благодат усиновљења“ (Свети Кирило Јерусалимски, Кайихезе, Београд - Ваљево - Србиње 2001,Тајноводствена 2, 6, 272).

7 Teodor Mopsuestijski, нав. gјело, 14, 21, 142.

8 Већ веома рано, код папе Виктора (189-199), први пут се помиње крштавање током Пасхалне ноћи. Касније ће се Пасхи придодати и Педесетница као додатно вријеме за 
и крштење вежу првенствено за тај догађај. Свједочанства о начину вршења катихизације у периоду четвртог и петог вијека сачувана су у више литургијско - канонских списа, као и у светоотачким дјелима. У том погледу, најзначајнији међу њима за нашу тематику јесу: Ийолитиови канони, Завје-

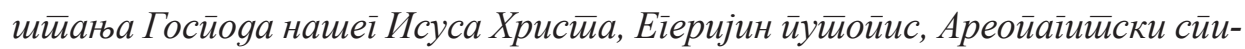

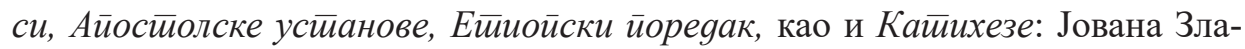
тоустог, Теодора Мопсуестијског, Кирила Јерусалимског и Амвросија Миланског. ${ }^{9}$

Крштења се у овом периоду обављају у посебним и намјенски саграЂеним просторијама, које се зову баптистерији ( $\beta \alpha \pi \tau \imath \tau \tau \eta ́ \rho \imath \alpha)$, то јест крстионице. Ове грађевине су се састојале из спољашњег дијела или „предвор-

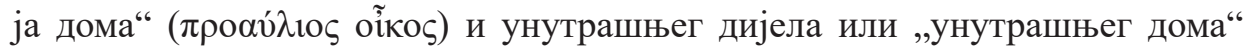

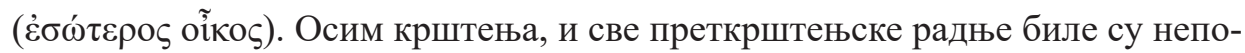
средно везане за тај простор. Последње катихизације, егзорцизми, присаједињење, исповиједање вјере, помазање преткрштењским уљем, све се то сада врши у просторима баптистерија. ${ }^{10}$

обављање пријема у Цркву. Пасхи и Педесетници почиње да се додаје и Богојављење, а онда и празник Рођења Христовог, онда када је установљен. Најзад, придодати су и празници апостола̂ и мученика̂. Тако, на Истоку крајем 11. вијека, а на Западу у 13. вијеку из црквене праксе нестаје утврђених термина за обављање пријема у Цркву. На тај начин се и обнавља пракса древне Цркве, у којој се, према Тертулијановим ријечима, држало да сваки дан јесте дан Господњи, и да је сваки сат и свако вријеме прикладно за крштење, и да ма колико ми уважавање гајили према празницима, благодат свете тајне их не потребује (уп. Kvint S. F. Tertulijan, Spis o krstu, Zagreb 1981, 19, 3, 85). Постепено напуштање неких утврђених термина за примање у Цркву било је узроковано слабљењем дисциплине међу катихуменима, а ово је, са своје стране, произилазило из тога што су већину крштаваних, готово без изузетка чинила дјеца. Такође, и због великог броја оних који су жељели да приступе Цркви, катихизација је била сажета на поучавање основним истина вјере. Све су рјеђи били случајеви крштавања одраслих, а и када би се то дешавало, није било неке израженије неопходности да се спроводи катихизација. У Византији цјелокупна организација живота почиње да се темељи на хришћанским начелима, те је и са̂м живот у извјесној мјери замјењивао институцију катихумената. Тако, са почетком 5. вијека катихуменат бива изложен потпуној деградацији која га је довела до његовог дефинитивног ишчезнућа, или ишчезнућа оног његовог обличја који је имао до 4. вијека. Међутим, литургијски израз катихумената је ипак остао сачуван у Цркви у свештенорадњи којом се постаје катихумен, а која се састоји у одрицању од пређашњег грјеховног живота и служења сатани (в. Афанасјев, нав. gјело, 56-58, 113-114).

9 в. Милошевић, Молитивослов, 21-22.

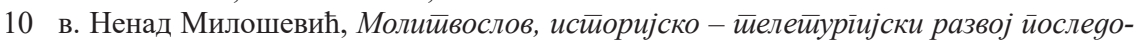
вања йарохијской йийика, Београд 2012, 23. „Katekumen bi pred krsni zdenac dolazio sa zapadne strane. Zapad je, kao strana zalaza sunca, tame, a time grijeha i ropstva, označavao stari život koji je kršćanin ostavljao upravo silaskom u krsni zdenac. Izabranik (electus) to je obredno iskazivao time što je pokorničku odjeću (cilicium) - koju je nosio u korizmenom vremenu pretkrsnoga čišćenja i prosvjetljenja, tkanu od tvari životinjskoga podrijetla, dakle sukna, kostrijeti, vune ili grube kože, čime se u antici simboliziralo ropstvo - odlagao na zapadnoj strani zdenca, te okrenut prema zapadu, izvoru tame i grijeha, pružao glasan iskaz odreknuća od Zla (renuntiatio a Satana). Nakon odreknuća, okretao se prema istoku i započinjao svoj exodus ili put iz zemlje ropstva prema zemlji 


\section{Период катихизације}

Црква у овом периоду прецизно разликује три реда ${ }^{11}$ оних који се припремају за свето крштење. Први ред су чинили они знатижељници који су припуштани слушању ријечи Божије на почетку литургије - познат под

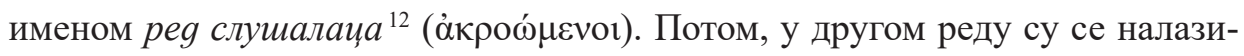

obećanja. Silazi u krsni zdenac, gdje je trostrukim uranjanjem u živu vodu [...] na otajstven način bio uranjan u Boga Oca i Sina i Duha Svetoga“ (Ante Crnčević, Inicijacijska dinamika u liturgiji krštenja od dinamike otajstva do obrednoga ustrojstva, y: Bogoslovska smotra, 79 (2009) 3, 512-513).

11 Мада, енглески научник Joseph Bingham (1668-1723) сматра да су, у најмању руку, постојала четири реда, и то: 1) они који су йоgучавани иривайно ван Цркве, 2) реg слушалаща, 3) они који клече и 4) они који су сиремани за нейосреgно крийеље. Прву и трећу групу, тј. оне који су подучавани приватно ван Цркве и оне који клече, Bingham утемељује на V канону Неокесаријског сабора (315.), у коме стоји: „Оглашени ако улази у Цркву (Kvplфкóv = Госйоgњи $(Х р а м /)$ и стоји у реду оглашених, па сагреши, ако је међу онима што клече, нека, више не грешећи, пређе у слушаоце (Св. Писма); а ако и као слушалац још греши, нека буде изагнан (ван Цркве)“. По питању реда слушалаца, Bingham се позива на XIV канон Никејског сабора (325.), који каже: „За оглашене који су пали (у време гоњења), Свети и Велики Сабор ӧдлучи: да (кад се обрате) само три године буду са онима који слушају (Св. Писмо), после тога нека се моле са оглашенима“. Док се за четврту групу оних који се спремају за непосредно крштење Bingham позива на Кирила Јерусалимског, Августина, и остале. Дакле, постоји извјесна несагласност око броја редова унутар катихумената. Модерно римокатоличко и протестанско учење прихвата само двије класификације катихумена. Источни и западни канони Цркве користили су различите називе за редове катихумената, али изгледа да су се слагали око њиховог броја (нпр. XIV канон Никејског сабора их дијели на оне који слушају и на иросвјећиване, док их V канон Неокесаријског сабора дијели на оне који слушају и оне који клече). Према Bingham-y, неки каноничари их дијеле на савршене и несавршене. Тако, сходно Ийолитиовим канонима, Айостиолским устиановама, разним канонима Цркве, Августину и неким писцима од другостепеног значаја, постојале су двије главне класификације катихумена, и то: 1) нижи ред катихумена (,чисти и прости“), некад нарочито назван катихуменима, и 2) виши ред или они који су се уписали за крштење и били спремни за преткрштењску катихизацију. Они су касније били познати као ирросвјетиљивани или изабрани (в. Lawrence D. Folkemer, A Study of the Catechumenate, y: Church History, Vol. 15, No. 4 (Dec. 1946), 287-289). О овоме види још у: Павел Гаврилюк, Иситория кайехизации в яревней церкви, Москва 2001, 214-216.

12 Они се на латинском називају rudes, тj. они који су неупућени у хришћанство, али који желе да му приступе (уп. Marijan Mandac, y: Sveti Avgustin, Poučavanje neupućenih, Makarska 1988, 17-18). Постојала је јасна разлика између слушалаца и кайихумена. Слушаоци никако нису могли бити убројани у ред катихумена све док не би показали и мишљу и владањем своју искрену и озбиљну намјеру да постану чланови Тијела Христовог. Такође, уколико би се показали недостојни звања катихумена, исти би били враћени у ред слушалаца, док се не би покајали. Постојала је, међутим, и код неких људи „прорачуната“ пракса одлагања крштења све до самртне постеље, будући да су знали да се крштењем опраштају сви претходни гријеси, па да не би опет пали у неке велике гријехе одлагали су крштење, али и због тога што је хришћанство захтјевало радикалну посвећеност јеванђелском начину живљења који успоставља строге епитимије за јавне грешнике. Тако да је и та строгост код многих довела до оклијевања и одлагања крштења, било због уважавања њихових људских слабости и светости Светих тајни, било једноставно због страха и цинизма. Све то је за резултат имало да је примање причешћа постане пракса само оних истински посвећених. Имајући у виду тако дубоко укоријењено оклијевање према примању Светих тајни, можемо видјети најмање један од трендова против којих су се борили велики мистагози четвртог вијека: Кирило Је- 


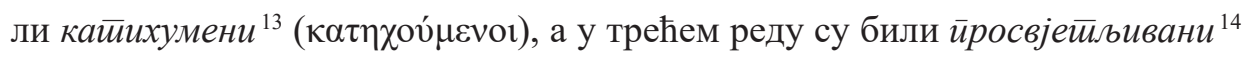

русалимски, Јован Златоусти, Амвросије и Теодор Мопсуестијски, пишући о двије основне хришћанске Свете тајне, крштењу и причешћу. Њихова намјера није била само да дају упутства, већ изнад свега да надахну и ојачају ријешеност оних који се спремају за ове Тајне. Они наглашавају значај, али и потребу за учешћем у светотајинском животу Цркве, које је неопходно, уколико су хришћани заиста озбиљни у намјери да живе у Христу и жељи за будућим вјечним животом (в. Фредерик Мек Леод, Теоgор Мойсуестиијски: Хрисииолошка иррожетиосии юеїової йоимања Кршйења и Причешћа, у: Годишъак, 14 (2015), 237-238). Онима који су одлагали своје крштење, Златоусти је скретао пажњу на неизвјесност смрти, али и указујући на свету тајну исповијести и покајања, како не би сматрали ништа важнијим од свог приступања Цркви (уп. Folkemer, нав. gјело, 289-290 и Свети Јован Златоусти, нав. gјело, I, 46, 28). Јер, иако је једном за свагда покајан кроз ,једно крштење“ хришћанин и даље неминовно остаје подложан гријеху и то је стварност са којом се вјерник суочава кроз цио свој овоземаљски живот (в. Милошевић, У Духу и истиини, литиуріичко - канонске йеме, Београд 2011, 18-19). О овом обичају одлагања крштења погледати још у: Гаврилюк, нав. gjeло, 184-186.

13 Они који би се међу rudes показали као подобни и достојни своје вјере, били би уврштени међу оне који су називани асcedentes, тј. иристиуйници у катихуменат (уп. Mandac, y: Sveti Avgustin, нав. gјело, 17). Постојао је нарочит обред примања у катихуменат, приликом кога би се на катихумена стављао крст, а вршен је и егзорцизам. Катихумену се давала освештана со, која је била сматрана počelom koje iscjeljuje, čisti i brani od štetnog đavoljeg utjecaja (в. Marijan Mandac, y: Sveti Ambrozije, Otajstva i tajne, Makarska 1986, 88). Стриктно гледјући, катихумени нису били чланови Цркве, већ су у одређеној мјери прихватани под окриље Цркве и убрајани су у један од црквених редова. Они су били дио хришћанске заједнице и сматрани су хришћанима, што потврђује Елвирски сабор (306. год) који их у свом XXXIX канону изричито назива хришћанима. Августин, рецимо, даје за право катихумену да се назива хришћанином, али ипак сматра да се он не може посматрати као један од вјерних (в. Folkemer, нав. яјело, 287).

14 Они су чинили засебну цјелину у оквиру катихумената, називани су још и competentes, electi и illuminandi, а једино у Јерусалиму су их називали тьбтоі́ (в. Афанасјев, нав. gјело, 109). То су, дакле, катихумени који се налазе на концу катихумената. Након крштења остају цијелу Свијетлу седмицу одвојена заједница која слуша мистагошке катихезе, и тада их називају неофитиима. Тек потом постају вјерници, у пуном смислу ријечи (уп. Mandac, y: Sveti Avgustin, нав. gјело, 17). Вишъе звање које новокрштени добија јесте звање лаика -

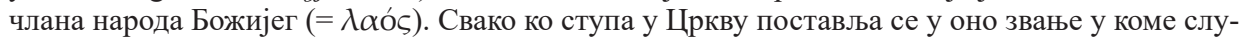
жи Богу и сваки вјерник јесте свешиееник Боїy и Ouy својемy (Отк 1,6$)$, али у том звању он не служи изоловано већ у склопу служења свег народа Божијег. Као што су у Старом Завјету свештеници и цареви бивали помазивани, тако и у Новом Завјету сви они који ступају у Цркву бивају помазивани, обучени у бијеле одежде и пострижени у знак потпуног предавања Богу (в. Афанасјев, нав. яјело, 19-20). Дакле, по примању крштења катихеза није прекидана, већ се са њом настављало, и сада се њен садржај углавном сводио на излагање учења о светим тајнама (в. Афанасјев, нав. gјело, 111), као што и свједочи Кирило Јерусалимски: „По Светом и Спасоносном дану Пасхе, почев од другог дана њезиног, сваког дана током седмице, сабираћете се на Свето место васкрсења и слушаћете друге поуке, ако буде воља Божија. Из тих поука сазнаћете о свему ономе што се са вама десило; све о чему будемо говорили биће подкрепљено цитатима из Старог и Новог Завета“" (Свети Кирило Јерусалимски, нaв. gjeло, $18,33,263)$. Свети Кирило као разлог одлагања мистагошке катихезе, коју он назива трпезом много савршенијег учења, наводи следеће: „Пошто знам да вид много боље уверава од слуха, стрпљиво сам чекао време, како бих вас кроз лично искуство нашао много спремнијима за слушање проповеданог и да вас припремљеније уведем у најсветлији и најмиомириснији врт овог раја““ (Истио, Тајноводствена поука $1,1,265)$. Да је поучавање вршено и након кр-

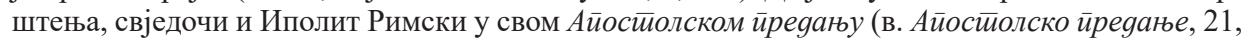
у: Дела айостиолских ученика, Врњци - Требиње 2005, 398-399). Међутим, Златоусти настоји 
(

Трогодишња катихизација је редован припремни период неопходан за приступање светој тајни крштења. ${ }^{16}$ Током овог периода катихумени би, прије свега, бивали поучавани основним истинама хришћанске вјере ${ }^{17}$, a сем тога катихизација је предвиђала и одвикавање од паганских обичаја и животних навика и очишћење од гријеха, као и вјежбање врлинског живљења и доброчинства. ${ }^{18}$ Такозвани Ийолийови канони (6. в.) не наводе тачно вријеме трајања катихизације, већ кажу да се катихумен може привести крштењу ако је за вријеме трајања катихизације посјећивао болеснике. ${ }^{19} \mathrm{Ta}-$ кође, ни Айосйолске усиианове (4. в.) не наводе тачно вријеме трајања катихизације катихумена, али, сходно опширном опису садржине коју катиху-

да још прије крштења катихуменима учини јаснијима симболичке и обредне свештенорадње које ће се збити, како би убирали йлоgове и йре но шиио почну gа уживају у великој слаgостии, gобивши већ саgа крила наgе, да би се йоказали разумнима и йонели се gостиојно свеїа ииоїа, и даље: да би мислили о ономе шиио је їоре, тј. да би своју йомисао йренели са земље на небеса, са вияљивог̆ на невияљиво (Свети Јован Златоусти, нав. gјело, II, 28, 36). И још вели, да би се c pagowћy и gуховним весељем припремили да приме благодат, да би уживали обилне gарове и да би сви зајеgно, показавши начином животиа да су достојни благодати, били удостојени да добију вечна и неизрецива яобра (Истио, II, 31, 37).

15 в. Милошевић, Молитивослов, 23, нап. 68.

16 У Теодоровим омилијама нема помена о дужини трајања катихизације.

17 Нису, наиме, сви подучавани на исти начин, како каже свети Григорије Ниски: „Onima pak koji pristupaju Riječi ne odgovara skroz isti oblik poduke. Stoga razlaganje treba upriličiti različitosti slušateljevih vjerskih osvjedočenja. Obuci je, doduše, sasvim isti cilj, ali uza sve to, u različitim slučajevima ne smijemo sezati za jednakim dokazima. Židov je prožet jednim pretpostavkama, a čovjek suživljen s grčkom naobrazbom drugima. Jednako vrijedi za anomejca, manihejca te Marcionove, Valentinove i Bazilidove sljedbenike kao i za preostali sloj ljudi koji zabludiše u krivovjerja. Svaki od njih nadasve cijeni vlastita osvjedočenja i nužnom čine borbu protiv njihovih polazišta. Način se, naime, liječenja mora prilagoditi vrsti bolesti“ (Grgur iz Nise, Velika kateheza, Makarska 1982, Proslov 1-2, 92).

18 Тако Теодор највећи дио својих омилија управо из тог разлога посвећује тумачењу Символа вјере, поучавајући оне који приступају крштењу какве мисли треба да имају и у чије име се крсте: ,,... da ste poučeni i da se krstite u ime Oca i Sina i Duha Svetoga“" (Teodor Mopsuestijski, нав. gјело, 12, 1, 104-105). Те да би се на тај начин брижно сјећали свега што им је говорио, и да чврсто и без промјене одрже богобојазну $(\theta \varepsilon о \sigma \varepsilon ́ \beta \varepsilon 1 \alpha)$ вјероисповијест, како би заиста уживали будућа добра (уп. Исйо, 10, 23, 90). Сем тога, да очувају и здраву савјест и искрену љубав, и да одабравши добро - то добро љубе и у потпуности га траже (уп. Истио, 11, 13-14, 99-100). У том смислу, Теодор доктринарном учењу придодаје моралну поуку, коју налажу обичаји његових паганских слушалаца. Он подсјећа да је потребно чувати се од многобожачких празновјерја, астрологије, гатања, обредних чишћења и прања, као и то да су позориште, циркус и стадиони забрањени, а као разлог за то наводи да све то đavao sije po

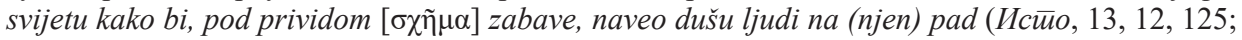
в. Т. Z. Tenšek y: Ист̄о, xxvi).

19 в. Canones S. Hippolyti, Monachii 1870, XIX, 2, 74. 
мени треба да савладају, очигледно да је за то био неопходан дужи временски период. ${ }^{20}$

Четрдесетодневни пост ${ }^{21}$, који је сада прерастао у општу претпасхалну црквену дисциплину, обавезујућег је карактера за све чланове Цркве. Вјеродостојним се може сматрати тврђење да су катихумени, заједно са осталим хришћанима, држали пост за вријеме Свете четрдесетнице и исповиједали своје гријехе ${ }^{22}$. Сама чињеница да су, управо у то вријеме, приступали завршним поучавањима, иде у прилог изреченом увјерењу. ${ }^{23}$ При обраћању катихуменима последње седмице поста, Кирило Јерусалимски јасно указује и на четрдесетодневни пост катихумена:

„Окончавши поприште поста задржи у сећању казано, принеси плод добрих дела да би, представши духовном Жениху, био удостојен опроштаја грехова од Бога.“ 24

20 в. The Constitutions of the Holy Apostles, New York - Philadelphia 1848, VII, XXXIX, 189-190. и Милошевић, Молийвослов, 23-24, и нап. 70. Чини се да је (први) период резервисан за катихумене био знатно дужи од (другог) припремног периода пред само крштење. На тај начин Црква је могла знатно ефикасније да се заштити од уласка под њено окриље оних који нису били сасвим искрени у својој намјери да јој приступе. Током првог периода, катихумен је био под константним надзором и поучавањем од стране Цркве, те је имао прилику да се докаже и покаже у својој одлучности да се крсти, прије него што буде прибројан у ред просвјетљиваних. Са сигурношћу се може рећи да је прелиминарна фаза катихизације просвјетљиваних била намијењена испитивању личних мотива оних који ће се крстити, као и усмјеравању тока личног развоја сваког просвјетљиваног појединачно. Тако, овај други период припреме очевидно јесте трајао краће, али је у том периоду катихумен интезивније, систематичније и пажљивије бивао испитиван и поучаван од стране Цркве (уп. Folkemer, нав. яјело, 291).

21 Пост пред Васкрс, који се постепено развио у Четрдесетницу, води поријекло од првобитних крштењских припрема катихумена. Након установљавања годишњег празновања Пасхе преткрштењски пост ће трајати прво пет, односно шест дана, а врло брзо ће се развити и у четрдесетодневни (в. Милошевић, Молийвослов, 14, нап. 17). Према Айосииолским устиановама сама дужина поста је варирала у зависности од гријеха сваког појединца, па је могао трајати двије, три, пет или седам седмица (в. The Constitutions of the Holy Apostles, II, XVI, 26).

22 Као што и свједочи Кирило Јерусалимски: „Садашње време представља време исповести. Исповеди све што си учинио речима или делима, дању или ноћу. Исповедај у вре-

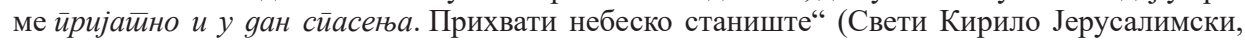
нав. gјело, 1, 5, 21). А на другом мјесту говори: „Четрдесет дана ти је одређено за покајање“ (Исиио, Уводна поука, 4, 11).

23 Теодор Мопсуестијски, наиме, нигдје у својим катихезама не помиње претпасхални пост, али познато је да је у овом периоду у Сирији пост пред Пасху засигурно држан, и то од Великог понедељка до Велике суботе, а завршаван је на Васкршње јутро (уп. Гаврилюк, нав. яјело, 203.).

24 Свети Кирило Јерусалимски, нав. gјело, 3, 12, 42. 


\section{Завршни период катихизације и крштење}

Они који би били уврштени у ред катихумена, уписивали су се у црквене књиге прије почетка Четрдесетнице, ${ }^{25}$ како би се крстили за предстојећу Пасху ${ }^{26}$, о чему Теодор Мопсуестијски свједочи:

„»Tko dakle želi pristupiti krštenju neka se prijavi Crkvi Božjoj« i po njoj se on pouzdaje stići u život u nebeskom boravištu. Ali, kako pristupa novomu i uzvišenomu gradu, i jer želi postati sinom toga grada, valja mu svom pomnjom (bahpituta) poraditi na tome da tu bude upisan. »Pristupa dakle Crkvi Božjoj. Primit će ga onaj koji je za to postavljen, budući da je običaj da oni koji pristupaju krštenju budu upisani..." 27

25 Фергусон у једној својој студији, осврћући се на 4. вијек, каже да је то уписивање катихумена који ће се крстити за предстојећу Пасху бивало почетком године, негдје око Богојављења (уп. Everett Ferguson, Preaching at Epiphany: Gregory of Nyssa and John Chrysostom on Baptism and the Church, y: Church History, Vol. 66, No. 1 (Mar. 1997), 1). Мада је тај упис вршен и касније, како видимо из XLV канона Лаодикијског сабора, који забрањује упис кандидата за крштење након друге седмице Четрдесетнице.

26 Уколико катихумени не би били спремни да се крсте за предстојећу Пасху, њихово крштење би бивало одложено, углавном до Педесетнице - у Западној Цркви то је био последњи рок за крштење. Али већ касније, Педесетница ће постати други крштењски празник, док ће у Источној Цркви то бити Богојављење (уп. Folkemer, нав. gјело, 290, нап. 31).

27 Teodor Mopsuestijski, нав. gјело, 12, 14, 110. Теодор о овом упису говори и још на почетку својих омилија: „Već smo dakle od sadašnjega časa zapisani, zahvaljujući tim neizrecivim otajstvima, za tu strahovitu proslavu budućeg svijeta" (Истио, 1, 4, 3). И нешто ниже у истој омилији каже: „Dakle, budući da svi oni koji su povjerovali Kristu očekuju boravište u nebu nakon uskrsnuća od mrtvih, - za nas je ta nada, uistinu, u nebu, ondje kamo je Krist ušao za nas, prije nas, - oni su uistinu upisani u to boravište posredstvom tih sakramenata“ (Истио, 1, 5, 3). За њега су Свете тајне истински типови који означавају најфундаменталнији ниво на којем ће вјерник учествовати у будућности, у Христовом васкрсењу (в. Мек Леод, нав gјело, 258). О овом уписивању налазимо свједочење и код Егерије, у њеном Пуйойису (4. в.): „Također treba da i to napišem na koji se način poučavaju oni što se krste za Uskrs. Onaj, naime, tko se upiše, dan se prije Korizme upiše. Svećenik pribilježi imena svih: to čini prije onih osam tjedana koliko se ovdje rekoh - obavlja Korizma“" (Egerija, Putopis, Makarska 1999, 45, 1, 237). Да су катихумени уписивани као хришћани, свједочи и Кирило Јерусалимски у Кайихезама (4. в.), гдје у обраћању катихуменима каже: „Ваша имена су већ уврштена у списак, па сте наречени и за војску и за брачне светионике и за желатеље небеског општежића и за добре намере и за наду која долази“ (Свети Кирило Јерусалимски, нав. gјело, Уводна поука, 1, 9). И мало ниже у уводном слову говори: „Ви, којима су имена записана у списку спремних за просвјећење, ви постадосте синови и ћерке једне мајке“ (Исйо, 13, 14). Такође, и свети Јован Златоусти у својим Кa-

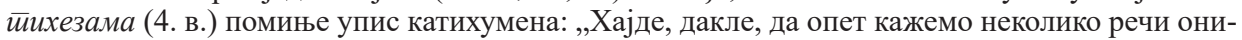
ма који су се уписали у војску Христову..." (Свети Јован Златоусти, нав. gјело, II, 1, 29), и на другом мјесту: „Сви ви, дакле, који сте се удостојили да се упишете у ову небеску књигу...“ (Истио, II, 9, 31). И свети Амвросије помиње gавање имена, што свакако упућује на овај упис катихумена (уп. Sveti Ambrozije, нав. gjeло, Spis o otajstvima, III, 2, 12, 171). Према Ареопагиту (5-6. в.), у књиге су уписивани и крштавани и воспријемници непосредно прије крштења (в. Свети Дионисије Ареопагит, О ирквеној јерархији, Шибеник 2009, II, 5, 13-14), што је случај и код Теодора (уп. Teodor Mopsuestijski, нав. gјело, 12, 16, 112). 
Приликом овога уписа, катихумен је морао имати некога od onih koji su privrženi tomu gradu u koji se on upisuje, тј. некога од вјерних ${ }^{28}$, који би ономе који уписује имена за крштење посвједочио о начину његовог живота, ima li sve potrebno da bi mogao postati stanovnikom toga tako uzvišena grada; jer valja mu se odreći sve zloće ovoga svijeta $i$ kad se od svega apsolutno udalji, čak $i$ $u$ duhu, tek onda postaje dostojan živjeti u tom gradu $i$ u njega biti upisan. ${ }^{29}$ Дакле, на основу свједочанства које ће дати његов јамац, који ће да потврди да ли се катихумен достојно припремао за крштење, он ће примити дар крштења. Јамац ће катихумена и да поучи свему што је потребно у његовом будућем живљењу, које ће да наступи. ${ }^{30}$

Како Егерија биљежи, они који се спремају за крштење бивају свакодневно поучавани од стране епископа током Свете четрдесетнице ${ }^{31}$, и то од првог до трећег часа дана. ${ }^{32}$ Док, непосредно прије почетка дневне катихезе, клирици над њима врше егзорцизме ${ }^{33}$. Сама катихеза се састоји у тумачењу

28 Ријеч је о воспријемницима, који су живо свједочили о ономе који жели да се крсти. Уколико они не би посвједочили да је онај који жели да се крсти узорног живота, онда би био враћен од стране епископа док се не би поправио. Дакле, тек ако би беспрјекорност његовог живљења била посвједочена од стране свједока, епископ би му дозвољавао да приступи купјељи (уп. Egerija, нав. gјело, 45, 3-4, 237-238). Сам Златоусти говори о воспријемницима, тј. кумовима као онима који се са очинском љубављу брину о напредовању својих духовних чеда - оних који се спремају за свето просвјећење, називајући их њиховим јемцима (в. Свети Јован Златоусти, нав. gјело, II, 15-16, 33), како их и сам Теодор назива (в. Teodor Mopsuestijski, нав. gјело, 12, 15, 111).

29 УП. Teodor Mopsuestijski, нав. gјело, 12, 14, 110-111. Златоусти је у том смислу изричит: „Ако неко није поправио своје мане и недоличан начин живота и није се већ припремио да врлински живи, нека се не крсти“ (Свети Јован Златоусти, нав. gјело, X, 7, 107).

30 Уп. Teodor Mopsuestijski, нав. gјело, 12, 15-16, 111-112. Обраћајући се катихуменима, Златоусти говори да тако треба да поступају и да се владају као да је Христос свуда са њима (уп. Свети Јован Златоусти, нав. яјело, I, 39-44, 26-27).

31 Било је, наиме, неопходно да се онима који се спремају за крштење, како говори Златоусти, gо иианчина уреже у ум истинско догматско учење Цркве, коме треба да приступе са сваком пажњом и да јачајући своју вјеру и животом је потврде, како би поставили чврсте темеље свом хришћанском живљењу (уп. Свети Јован Златоусти, нав. gјело, I, 20-25, 20 21). А сем тога, било је потребно и да узрастају угледајући се на узвишена етичка и аскетска начела (уп. Folkemer, нав. gјело, 291). У погледу аскезе, период припреме за крштење током Четрдесетнице није био лак. Катихумени су непрестано подстицани да, колико је то могуће, прибјегавају молитвеном тиховању (уп. Истио, 294). У том смислу и свети Кирило савјетуje: „Остави садашње, а веруј будућем. Толико година си провео у залудним бригама и пословима овог света, па зар нећеш током четрдесетодневне припреме посветити себе молитви на

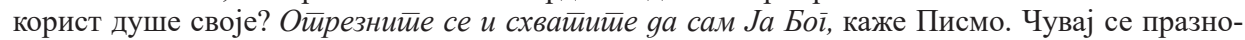
словља: не говори о другом ружне речи, нити слушај било кога ко говори ружно; свагда буди готов на молитву. Покажи се као затвореник, повучен у себе“ (Свети Кирило Јерусалимски, нав. дјело, 1, 5, 21).

32 Мада, како видимо код Кирила, катихезе су се одржавале и увече (уп. Свети Кирило Јерусалимски, нав. яјело, 8, 1, 93 и 11, 1, 117).

33 Златоусти, пак, вели да су након свакоgневне йоуке катихумени препуштани заüрећењима изїонииељља gемона: „Пошто вас након наше поуке преузму, они су ту зато да 
Писма (дословно и духовно). ${ }^{34}$ Овом поучавању присуствују и воспријемници, али и од вјерника ако ко жели може слушати поуку, међутим не и они који се неће крстити те године. ${ }^{35}$ Шесте и седме седмице Поста епископ тумачи Символ вјере, исто као што је тумачио и Писмо. Након седме седмице епископ је обављао испитивање катихумена ${ }^{36}$, провјеравајући на тај начин да ли су научили Символ вјере. ${ }^{37}$

оним страшним речима очисте цело ваше унутрашње биће као да припремају боравиште цара који треба да дође, будући да ће се у вама настанити Цар небески" (Свети Јован Златоусти, нав. gјело, II, 12, 32). У вези са заклињањима, Кирило Јерусалимски говори: „Заклињања прихватај побожно и ако на тебе дувају, ако те заклињу, све то прихвати ради спасења. Ако из грубог злата, помешаног са бакром, оловом, железом или дрветом, желимо поново да издвојимо злато, нећемо то моћи без пламена; злато не може бити очишћено од осталих примеса без пламена; тако и душа не може бити очишћена без заклињања“ (Свети Кирило Јерусалимски, нав. яјело, Уводна поука, 9, 12).

34 Несумњиво је да су катихумени током катихизације слушали ријеч Писма, што нам свједочи и сам Кирило Јерусалимски, који се на неколико мјеста у својим катихезама позива на претходно прочитани светописамски текст (уп. Свети Кирило Јерусалимски, нав. gjeло $14,2,173 ; 15,13,198 ; 15,21,203 ; 15,31,209 ; 17,4,229 ; 18,11,252$; Тајноводствена поука: $1,10,268$ и $3,7,276)$. Поред ове светописамске егзегезе, катихуменима је у почетку излагано и апостолско вјеровање са потпуним тумачењима. Сем тога, теме свакодневних поучавања биле су, наравно, и: вјера, Божије јединство, Божија самовласност, Оваплоћење, Распеће, Васкрсење и Вазнесење Христово, Други долазак, Последњи суд, Дух Свети, католичанска Црква и живот вјечни, и тако даље (уп. Folkemer, нав. gјело, 292).

35 в. Egerija, нав. яјело, 46, 1-3, 239. У спису Завјешйањь Госйоgа нашей Исуса Хри$c \bar{u} a(4-5$. в.) наилазимо на исто овакво свједочанство: „Нека народ свакодневно борави у храму током Четрдесетнице пред Пасху, бдијући, молећи се и слушајући Писма, химне и речи поучавања“" (Testamentum Domini nostri Jesu Christi, Moguntiæ 1899, II, VIII, 127). И Амросије Милански (4. в.) говори о свакодневном поучаванју: „О с́udorednim pitanjima govorismo svaki dan“" (Sveti Ambrozije, нав. gјело, Spis o tajnama, I, 1, 200).

36 У неким Црквама ово испитивање је вршено и двадесет дана прије крштења, или пак на празник Цвијети (уп. Folkemer, нав. gјело, 292-293). Међутим, XLVI канон Лаодикијског и LXXVIII канон Трулског сабора налажу да се испитивање Символа вјере врши четвртком сваке седмице. У сваком случају, постојао је нарочит дан за то намијењен.

37 в. Egerija, нав. gјело, 46, 3-6, 239-240. Прихватање Христа у Символу вјере значило је и одрицање од сатане. Требало би напоменути и то да су катихумени молитву Господњу, коју Августин назива oratio fidelium (= молитва вјерних), примали тек након крштења, јер нико није могао рећи Оче наш док не би био препорођен бањом новога рођења. Углавном није било уобичајено да молитву Господњу изговарају прије него што се крсте, али Августин ипак указује да су је изговарали осам дана прије крштења. Дакле, ова молитва је одлагана такорећи до последњег тренутка, све док катихумени не би показали спремност да ју је приме (уп. Folkemer, нав. gјело, 293). 
Упису катихумена следује њихова исповијест ${ }^{38}$, коју Теодор назива postupak velike presude ${ }^{39}$ против ђавола koji od početka živi ratujući protiv nas kao neprijatelj, ali koji naročito sada nama zavidi zbog onoga što očekujemo da ćemo primiti tim neizrecivim upisom ${ }^{40}$. Након исповијести, пошто буду испитани, катихумени се припуштају егзорцистима, који су jamci božanske potpore и који ће дугим мољењима да се обраћају Богу да их ослободи од напасти мрзитеља. ${ }^{41}$ Они над којима се врши ово заклињање, кајући се за своје пређашње гријехе, чине овако:

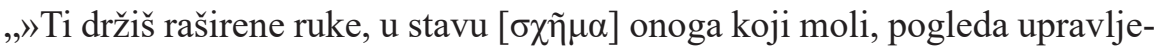
na prema dolje«, ostaješ tako kako bi privukao smilovanje suca. »Zato, nakon što si svukao izvanjsku odjeću, stojiš bosih nogu«, kako bi izrazio to zlobno ropstvo

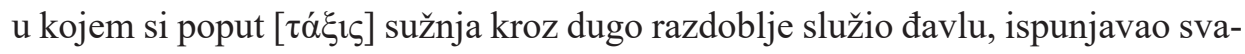
ki njegov nalog, kako je on tražio; i zato se naklanjaš pred sucem da ti se smiluje, budući da je to stav $[\sigma \chi \tilde{\eta} \mu \alpha]$ sužnja prema riječi Božjoj...“42

38 Златоусти говори да иако је човјек лишио своју душу и своје тијело њихове красоте увећавајући кроз гријех своју ружноћу (уп. Свети Јован Златоусти, нав. gјело, I, 5, 16), довољно је да само у једном трену жудно йожели да похита под Христиов јарам (уп. Исиио,

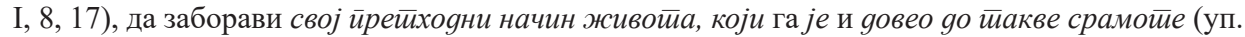
Истио, I, 9, 17) и Господ ће га са радошћу узети к себи и такву душу ће назвати својом кћери и неће тражити од ње да одговара ни за какаве кривице, него ће јој још и рећи да заборави све то (уп. Истио, I, 6-7, 16-17). Колико је то све чудесно, и колико је велика тајна тај брак душе човјекове са жеником Христом (в. Еф 5, 31-32), Златоусти настоји да то истакне упоређујући га са светиовним венчањем, јер вели, када дјевојци дође вријеме да се уда она забо-

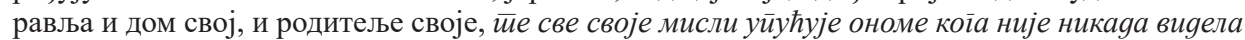
gо иее вечери и од тог трена њен женик за њу постаје све, а њихово сјеgињење йосииаје тиолико чврсӣо gа они више нису gвоје, неїо јеgно (уп. Свети Јован Златоусти, нав. gјело, I, 11-12, 17-18). Али, ниједан женик не би прихватио да узме себи за невјесту неку дјевојку уколико

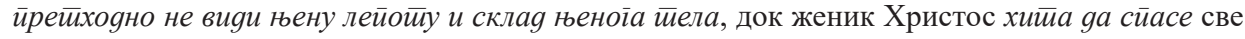
gуше, не гледајући на њихов излед (уп. Истио, I, 14-15, 18-19), јер љубав Христова је толико неизрецива и безмјерна да досеже до самог Крста, и Он крв своју пролива за Цркву своју, $\kappa a-$ ко би нас својим мноїобројним доброчинстивима йривукао сйарағу за наме сойсиввено сйасеюе (уп. Истио, II, 2, 29-30 и Еф 5, 25-27).

39 Teodor Mopsuestijski, нав. яјело, 12, 17, 112.

40 Teodor Mopsuestijski, нав. яјело, 12, 19, 113.

41 Teodor Mopsuestijski, нав. gјело, 12, 22, 115. Теодор ова заклињања која врште егзорцисти назива парницом или рочиштем ( $\alpha \gamma \omega \dot{\omega} v)$ против ђавола (уп. Ист̄о $, 12,26,117)$, у коме Божанска пресуда ослобађа од ропства ђаволу оне над којима се ово заклињање врши (уп. Истио, 13, 1, 119). Сам чин Теодор описује овако: „... u egzorcizmima koji se vrše dok ti stojiš

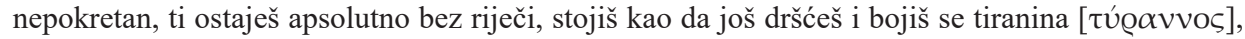
nemoćan čak pogled u nj upraviti, zbog golema zla kojim se služio protiv tebe i protiv tvojih otaca, odvodeći vas u ropstvo i za dugo vrijeme podjarmljujući vas teškim i okrutnim ropstvom, nanoseći vam neizlječive rane presudom smrti; odavna (min ruhqa) vas držaše u ropstvu koje ste navlačili na sebe." (Истио, 12, 23, 115-116).

42 Teodor Mopsuestijski, нав. gјело, 12, 24, 116. На сличан начин и Јован Златоусти говори: „Као што они који трпе телесно сужањство својим држањем показују свој јад због несреће која их је снашла, тако и они који су постали ђаволови сужњи, пошто ће се ослободити његове тиранске власти и ставити под добри јарам, целокупним држањем сами себе подсе- 
Током ових дана, када се врше исповијести и егзорцизми, ${ }^{43}$ катихумени нису беспослени него вријеме проводе у молитви, чешће изговарајући Символ вјере, који су научили током катихизације и који им је нашироко био протумачен, како би им се чврсто усадило у њихов ум, еда би још више завољели своју исповијест вјере, jer bez toga ne bi mogao primiti božanski dar, niti, primivši ga, biti čvrst u njegovu držanju. ${ }^{44}$

Затим, пошто су ослобођени ропства ђаволу, катихумени бивају привођени првосвештенику пред којим врше исповијест вјере и полажу завјете Богу, тј. да ће до краја истрајати у вјери коју исповиједају и којој су поучени, еда би били удионичари небеских добара. ${ }^{45}$ Како Теодор говори, катихумени су пред првосвештеником изговарали Символ вјере:

„Izgovarajući pred njim Vjerovanje, s Bogom po njemu sklapamo pogodbu i ugovor, (Bog) je taj kojemu, u tim ispovijedanjima vjere, obećajemo da ćemo mu biti podložni, služiti mu i zauvijek ustrajati te trajno i bez promjene čuvati njegovu ljubav." 46

\section{Овом исповиједању вјере слиједи одрицање од Сатане: ${ }^{47}$}

ћају на свој претходни положај, како би били свесни од кога се ослобађају и под чију заштиту се стављају и како би им то био повод за још већу захвалност и благодарност“ (Свети Јован Златоусти, нав. яјело, II, 14, 33).

43 Егзорцизми су у Антиохији вршени након дневне катихезе, а не прије ње, као што је то био обичај у Јерусалиму (уп. Гаврилюк, нав. яјело, 188).

44 в. Teodor Mopsuestijski, нав. яјело, 12, 25, 116. XLVI канон Лаодикијског сабора налаже да новокрштавани уче наизуст Символ вјере.

45 Уп. Teodor Mopsuestijski, нав. gјело, 12, 26, 117. Како дознајемо из Ийолийових канона, катихумени се купају у четвртак прије крштења и једу, док у петак посте (в. Canones $S$.

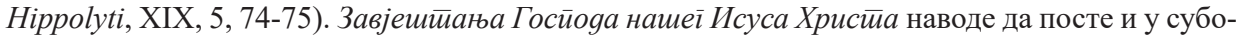
ту (в. Testamentum Domini nostri Jesu Christi, II, VI, 121). Такође, и Айосйолске усиианове прописују пост прије крштења: „Штавише, прије крштења, наложи ономе који ће бити крштен да пости" (The Constitutions of the Holy Apostles, VII, XXII, 174). Свети Кирило Јерусалимски као разлог скраћивања своје дневне катихезе наводи умор који је узрокован дуготрајним постом, који је био у петак, као и због бдења (уп. Свети Кирило Јерусалимски, нав. gјело, 18, 17 , 256). Купање се врши највјероватније из практичних разлога, првенствено због тјелесне чистоће при крштавању, а онда и због немогућности осмодневног умивања после крштења (в. Милошевић, Молийвослов, 27, нап. 74).

46 Teodor Mopsuestijski, нав. яјело, 12, 27, 117.

47 Према Ийолийовим канонима, катихумени се окупљају у суботњи дан заједно са епископом, и када клекну и окрену се према истоку, епископ полаже на њих руке молећи се gа изађе лукави gух из свих уgова њихових. Онда им дува у лица и осјењује њихова прса и чела, и уши и уста. И од тада се чувају да се лукави дух, кога су ослобођени, не врати опет на њих због њихових дјела (в. Canones S. Hippolyti, XIX, 6, 75). У Aйосйолским усйановама, пак, изричито се заповиједа одрицање од ђавола: „И када се приближи сами тренутак крштења, нека катихумен буде поучен о значају одрицања од ђавола и присаједињења Христу... Нека, дакле, кандидат за крштавање изјави у свом одрицању: Ogричем се Caйaне, и gјела њеі̄oвих, и раскоши [pomps] юеі̄ове, и служеюа юему, и анђела юеїових, и измишљойина

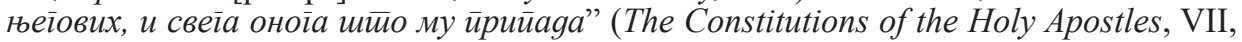


„Ponovno stojite uspravno na gruboj tkanini, bosonogi, nakon što ste odlo-

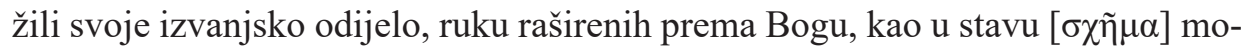
litve. ${ }^{48}$ Najprije ste na koljenima: kleknete, ali ostali dio tijela je uspravan. ${ }^{49}$ Tada govoriš: Odričem se Sotone, svih njegovih anđela, svih njegovih djela, i svega njegova služenja, sve njegove taštine i sve njegove svjetovne zabludjelosti..." 50 XL-XLI, 190-191). У Ийолитиовим канонима крштавани се непосредно прије крштења и помазивања егзорцистичким уљем окреће према западу и говори: „Одричем те се [Abrenuncio tibi], Сатано, са свом поворком твојом [роmpa tua]" (Canones $S$. Hippolyti, XIX, 9, 75). Код Ареопагита је изложено да одмах по упису имена крштаваног у књигу, епископ проузноси молитву, а свештеници затим свлаче одјећу са крштаваног. Затим се окреће према западу и епископ му заповиједа да трипут дуне на сатану и да изговори ријечи одрицања. Онда га епископ трипут пита да ли се одриче сатане и крштавани му такође исто толико пута одговара да се одриче (в. Свети Дионисије Ареопагит, нав. gјело, II, 6, 14). О одрицању непосредно пред само крштење говори и свети Кирило Јерусалимски: „Ви сте најпре ушли у предворје крстионице, окренути лицем према Западу, слушајући речи и по заповести пружајући руке своје као да терате сатану који се тамо налази... Тада си чуо заповест да пружиш твоје руке као према некоме ко ти је у близини и да кажеш: оgричем тие ce, caйано! ... Затим си поучен да одрицању своме додаш: и свих gела йвојих. ...После то-

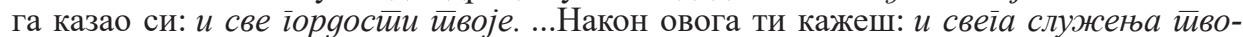

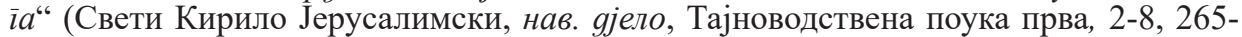
268). У катихезама светог Јована Златоустог наилазимо на свједочење да свештеник, ирисииуиајући свакоме ионаособ, иражи својевољни иристианак и исиовеgање вере, подстичићи их да кажу: „Одричем се, сатано, и тебе и твојих анђела и служења теби и свих твојих дјела“" (Свети Јован Златоусти, нав. gјело, II, 18-20, 34-35). Али, на основу Златоустове последње катихезе видимо да су за његовог времена у Константинопољу одрицање, сједињење и помазање вршени на Велики петак у девети час, одвојено од самог чина крштења (в. Истио, XII, 6-10, 129-131). Подсјећајући новопросвијећене, током својих мистагошких катихеза, шта се дешавало при њиховом крштењу, свети Амвросије Милански каже: „Kad te pitao: Odričeš li se đavola $i$ njegovih djela? Što si odgovorio? - Odričem! - Odričeš li se svijeta i njegovih požuda? Sto si uzvratio? - Odričem! Sjećaj se svoje riječi i neka ti se nikada ne uništi posljedica tvoga jemstva" (Sveti Ambrozije, нав. gјело, Spis o otajstvima, II, 5, 152-153). Да је крштавани ово одрицање вршио окренут према западу, види се из Амвросијеве ријечи на другом мјесту, гдје говори да се он након одрицања окреће према истоку (в. Ис$\bar{u}$ o, Spis o tajnama, II, 7, 201).

48 На овај начин се опомињу старих зала и старог ропства, ком тиранину су робовали прије заклињања (уп. Teodor Mopsuestijski, нав. gјело, 13, 2, 120).

49 „U stavu nekoga tko moli, upravljate ruke prema Bogu. Svi smo mi upali u grijeh i smrtna osuda bacila nas je na zemlju... treba da prignete koljena i pokažete svoj stari pad te iskažete poklonstvo Bogu, uzroku (svih) dobara... To je neka vrsta traženja da se vi tim stavom [ $\sigma \chi \tilde{\eta} \mu \alpha]$ obraćate Bogu i molite ga vapijući da vas istrgne iz vašeg starog pada pa da sudjelujete u nebeskim dobrima“" (Teodor Mopsuestijski, нав. gјело, 13, 3-4, 120).

50 Teodor Mopsuestijski, нав. gјело, 13, 119. Теодор ове ријечи одрицања опширно разлаже и објашњава: ,„.. zato kažete »Odričem se Sotone«, označujući istodobno prethodno zajedništvo (šautaputa) koje ste imali s njim i od kojeg se sada odvraćate; jer nitko ne kaže »Odričem se« nečega u čemu prije nije imao nikakva udjela (šautaputa)... Ali kako je on nevidljiv, u ratu protiv nas znade se služiti vidljivim stvarnostima, onim ljudima koje je jednoć pokorio, od kojih čini sredstva svoje zloće i kojima se služi da padnu drugi, zbog toga dodaješ ('ayti) »i svih njegovih anđela«... Nakon što si kazao: »Odričem se Sotone i svih njegovih anđela«, proslijediš ('ayti) »i svega njegova služenja«. Isto onako kao ljudi (koji su) u službi prohtjeva Zloga, ti ćeš jednako tako 
Захваљујући заклињањима, они су сада у стању да га се сами одрекну, и то онако како их ђакони поуче и припреме да то кажу, ${ }^{51}$ јер од свега тога треба да се одрекну они који ће постати учесници тајне Новога Завјета, они који су уписани да буду грађани неба, наследници будућих добара, који очекују препород крштења, ${ }^{52}$ те се одмах присаједињују Богу:

„... zavjetom se obvezujem, vjerujem ${ }^{53} \ldots$

s gnušanjem nastojati odvratiti se od svega što se čini pod imenom nauka, jer toje očito bezbožnost. Sve služenje (tešmešta) Sotoni je od poganstva... Ti još kažeš: » I sve njegove taštine«. Sotonska taština postaje jasan izraz ako se ima na umu sve što se čini kod pogana pod imenom nauka; jer sve što oni šire pred licem svega svijeta, čine iz taštine, da zadive gledatelje i smute ostale... Nakon toga ti kažeš: »I sve njegove svjetovne zabludjelosti«. Ono što se naziva »njegova zabludjelost«

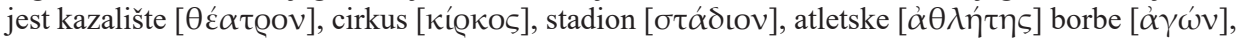

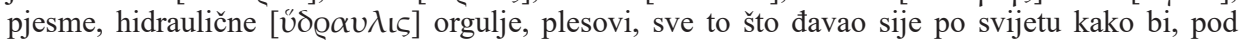
prividom $[\sigma \chi \tilde{\eta} \mu \alpha]$ zabave, naveo dušu ljudi na (njen) pad“ (Исйo, 13, 5-12, 121-125). Оно због чега се овде убраја и позориште, јасно је из Кирилових ријечи: „Немој у себи подстицати жељу за гледањем неморалних позоришних представа у којима ћеш видети разголићене актере, који бестидно и сасвим непотребно изводе срамотне плесове и игре“" (Свети Кирило Јерусалимски, нав. яјело, Тајноводствена поука 1, 6, 267).

Свети Кирило Јерусалимски свједочи да је ово одрицање вршено у предворју крстионице. Наиме, онај који се одрицао Сатане, окренуо би се лицем према западу, слушајући ријечи и по заповијести би пружао своје руке као да тјера Сатану који се тамо налази и тада би

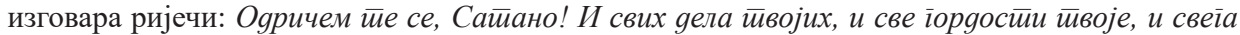
служењ а иввоїа (в. Свети Кирило Јерусалимски, нав. яјело, Тајноводствена поука 1, 2-8, 265 267). Разлог овог окретања ка западној страни јесте следећи: „У односу на нас, тамна страна света је Запад, а сатана, будући сам тама, у тами гради и има своју моћ: ради тога се окренусте Западу и одрекосте тог тамног и мрачног кнеза" (Свети Кирило Јерусалимски, нав. gјело, Тајноводствена поука $1,4,266)$.

51 УП. Teodor Mopsuestijski, нав. яјело, 13, 5, 121. У вези са овим такође погледати: Свети Јован Златусти, нав. gјело, II, 14, 33, који даје готово идентичан опис.

52 Уп. Teodor Mopsuestijski, нав. gјело, 13, 12, 125.

53 У Ийолийовим канонима исповиједање вјере се састоји из два дијела, при чему први бива непосредно пред само крштење (в. Милошевић, Молийвослов, 29, нап. 77). Крштавани, прије него што сиђе у воду и након што буде помазан егзорцистичким уљем, говори овако: „Верујем и клањам се пред Тобом и пред свом поворком Твојом [militia tua], Оче и Сине и Душе Свети“ (Canones S. Hippolyti, XIX, 10, 76). У Айостиолским устиановама, одмах по присаједињењу, крштавани додаје: „И вјерујем и крштавам се у једног нерођеног Бивствујућег, јединог истинитог Бога Сведржитеља, Оца Христовог, Творца и Створитеља свих, кроз којега је све..." (The Constitutions of the Holy Apostles, VII, XLI, 191), и тако редом излаже један цјеловит Символ вјере. Сходно Светом Кирилу Јерусалимском, исповиједање вјере се

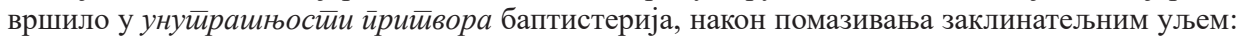
„Потом [након помазивања] сте доведени до Свете купељи божанског крштења, као што је Христос био преведен од Крста до свога гроба. Сваки од вас је тада био упитан да ли верује у име Оца, Сина и Духа Светога? Ви тада исповедисте спаситељно исповедање, погружавајући се трократно у воду и израњајући из ње“ (Свети Кирило Јерусалимски, нав. gјело, Тајноводствена поука друга, 4, 271). На основу наведеног свједочења, није сасвим јасно да ли је Символ вјере, који Кирило тумачи у шестој огласитељној поуци, па све до осамнаесте, изговаран у одређеном временском тренутку прије крштења, па су крштавани непосредно пред са̂мо трократно погружавање потврдно одговарали на питање свештеника да ли вјерују у Оца и Сина и Светога Духа, или је пак исповиједање било садржано само у овој последњој форми (в. Милошевић, Молийвослов, 29, нап. 77). Други дио исповиједања према Ийолийовим 


\section{... i krstim se u ime Oca, Sina i Duha Svetoga.“54}

Чиме показују да ће чврсто остати уз Бога и да ће одсад бити непоколебиви, и да се ни на који начин неће од Њега одвратити, и да вјерују у сва добра која су им припремљена. ${ }^{55}$ А затим првосвештеник знаменује крштаваног по челу уљем помазања, говорећи:

канонима бива у комбинацији са крштењском формулом. Крштавани силази у воду, а презвитер, пошто положи руку на његову главу, пита га: „Верујеш ли у Бога, Оца, Сведржитеља?”, и пошто одговори да вјерује, бива погружен у воду. Тако бива испитан за сва три лица Свете Тројице појединачно, и након сваког исповиједања презвитер га погружава у воду (в. Canones S. Hippolyti, XIX, 11, 76). Слично је и у Завјешйањьу Госйоgа нашеї Исуса Христиа (в. Testamentum Domini nostri Jesu Christi, II, VIII, 127-131).

54 Teodor Mopsuestijski, нав. gјело, 13, 119. Сматра се да на Истоку, све до 4. вијека, нема помена о присаједињењу (уп. Милошевић, Молийвослов, 29, нап. 77). Свети Кирило такође говори о присаједињењу: „Пошто си ово све казао, окренуо си се од Запада према Истоку и тада ти је заповеђено да кажеш: верујем у Оиза и Сина и Свейоїа Духа, и у јеgно крииееюе йокајања" (Свети Кирило Јерусалимски, нав. яјело, Тајноводствена поука 1, 9, 268). Исто тако и Златоусти, говорећи: „... након што сте се одрекли злога и свега онога што се на било који начин тиче њега, свештеник вас опет подстиче да кажете: Сјеgињујем се с Тобом, Хриcйе“ (Свети Јован Златоусти, нав. gјело, II, 21, 35). Златоусти вели да се овим ријечима одрицања од сатане и присаједињења Христу склапа сйоразум са Господом, вером и исйовеgањем (Исиио, IV, 31, 54). А услови споразума су да се више не враћа злу, него да живи Христом у кога се и облачи. Господ је овдје залогодавац који крштаваноме дарује непролазне дарове, који нису пропадљиви него су духовни и небески. Зато и говори: „Треба, дакле, да се потпише документ не на хартији и не мастилом, него у име Божије, благодаћу Светога Духа. Јер се речи које се тада изговарају записују на небесима, а споразум који се усмено изговара остаје неизбрисиво у сећању Господњем“ (Ист̄о, II, 17, 34). И још говори да, пошто примамо и хранимо се тим освећеним Даровима - тијелом и крвљу Христовом - којима нас је Христос са самим собом сјединио, онда треба да йокажемо велику усреgности и йамйимо услове сйоразума који смо склойили с Њим, јер о йе хране се сасииојимо и њоме се хранимо (Исйо, III, 1920, 42-43). На другом, пак, мјесту, правећи поређење изеђу крштења и вјенчања, рећи ће слиједеће: „Као што се код склапања сваког брака прво склапају уговори и споразуми о миразу и брачним даровима, тако и овде бива пре венчања: нагу те [Христос] затекао и сироту и ружну и није те презрео, јер једино тражи твоје произвољење. Уместо мираза, дакле, ти Му донеси ове речи [= ријечи одрицања од сатане и сједињења са Христом] и Христос ће их сматрати великим богатством ако их будеш држао за свагда, јер Христово богатство је спасење наших

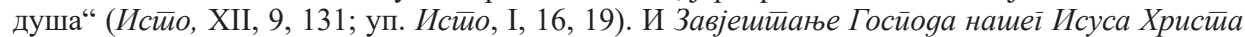
свједочи о присаједињењу: „Кажи: Припадам Ти, Оче, Сине и Свети Душе, пред којим свака природа дрхти и боји се; дај ми да Ти све најбоље без порока чиним“" (Testamentum Domini nostri Jesu Christi, II, VIII, 129). И Айосйолске усйанове прописују: „И, након овог одрицања, оставите му да у свом посвећењу каже: И присаједињујем се Христу“ (The Constitutions of the Holy Apostles, VII, XLI, 191). На основу списа св. Дионисија Ареопагита, крштаваног епископ окреће према истоку одмах по одрицању и заповиједа му да се сједини са Христом и свим богопреданим свештенодејствима. А када то учини, епископ онда од њега тражи трократно исповиједање, те се потом моли и благосиља крштаваног, полажући руке на њега (в. Свети Дионисије Ареопагит, нав. яјело, II, 6-7, 14).

55 Уп. Teodor Mopsuestijski, нав. gјело, 13, 14, 126. ,...jer vjerom u ono što će biti ti pristupaš daru svetoga krštenja, u cilju preporođenja, da umreš i da uskrsneš s Kristom, kako bi nakon što si tako primio drugo rođenje umjesto prvoga, mogao imati udio (šautaputa) u nebu“" (Иc$\bar{u} o, 13,14,126)$. За Теодора ово друго рођење јесте слика оног страшног рођења - васкрсења из мртвих, којег је крштење залог и сигурност да ћемо га задобити: „Nema (mjesta) čuđenju što mi primamo dvostruko rođenje, i što prelazimo iz ovoga u ono, budući da ('ayka d) i u našem 


\section{„Znamenovan je Taj, u ime Oca i Sina i Duha Svetoga.“ 56}

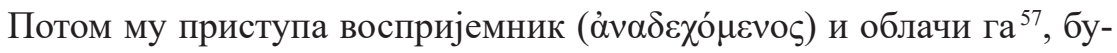
дући да је претходно био наг, стављајући му ланени рубац ${ }^{58}$ (ઢ̊ópıov) на главу, који симболише слободу у коју је позван, и подиже га усправно, чиме показује да је напустио свој некадашњи пад и да нема више никаквог удјела са земљом и са земаљским пословима. ${ }^{59}$

Након тога крштавани приступа крштењу. ${ }^{60}$

tjelesnom postajanju imamo dvostruko rođenje, jedno od muškarca i potom drugo od žene. Najprije, u sjemenu, nastajemo od muškarca a da još nema tragova ljudske sličnosti. Jasno je naime svakomu da sjeme nema nikakve ljudske sličnosti; ali kad se, po zakonima [vó vio u ljudsku narav, sjeme začne i oblikuje, nakon što je zadobilo oblik i začelo se u ženi, tada zadobiva sličnost ljudske naravi. Na takav se način i mi rađamo; najprije u sjemenu po krštenju, a da još nismo rođeni u besmrtnu narav u koju očekujemo da ćemo prijeći po uskrsnuću, sličnost kojega još nismo zadobili. Ali kad se, po vjeri i nadi u ta buduća (dobra), za njih odgajamo i oblikujemo kršćanskim ponašanjem, (nakon što) smo ustrajali sve do vremena uskrsnuća, tada, prema božanskoj odredbi, iz praha ('adamta) ćemo zadobiti drugo (dmen dreš) rođenje i primit ćemo onu besmrtnu i nepropadljivu narav, kad Gospodin naš Isus Krist preobrazi ovo naše bijedno tijelo, prema

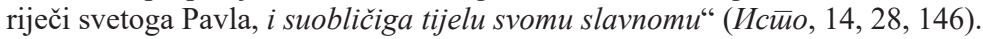

56 Teodor Mopsuestijski, нав. gјело, 13, 17, 127. „Ali to znamenovanje (rušma) kojim si sada označen, znak je da si odsada obilježen kao ovca Kristova, kao vojnik nebeskog Kralja“"

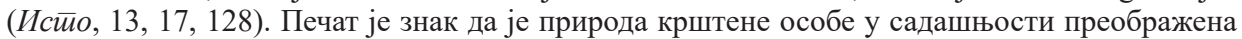
на начин који ће у потпуности бити испуњен у будућем вијеку: ,... odsad trebate pristupiti sa-

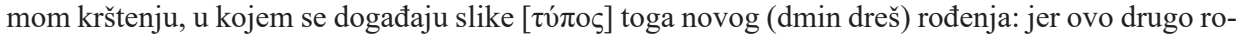
đenje, istinsko, koje će se tada obistiniti, vi ćete primiti kad budete uskrsnuli od mrtvih..." (Истио, $14,2,131)$. Тако, испуњење ће се догодити у будућности, али је процес већ започет (в. Мек Леод, нав. яјело, 259).

57 „Пошто си скинуо са себе овештале хаљине и обукао нову одећу, духовну и белу, приличи ти да свагда, у свако време, носиш белу одећу. Наравно, ми овде не кажемо да ти стално мораш бити обучен у одећу беле боје, него под белином подразумевамо светле и светлоносне хаљине (тј. духовно светле): овако треба да изгледаш да би заједно са блаженим Исаијом могао казати: нека се узраgује gуша моја у Госйоgу: обукао ме је у оgeћу сйасеға и одежgом весеља оgену ме“ (Свети Кирило Јерусалимски, нав. gјело, Тајноводствена поука $4,8,280$ ).

58 Ланени рубац су у Римској империји могли носити само слободни грађани. Овај ритуални чин је симболично показивао да сваки крштавани, без обзира на његов социјални положај, престаје бити слуга Сатани и постаје слободњак Исуса Христа (уп. Гаврилюк, нав. яјело, 205).

59 Уп. Teodor Mopsuestijski, нав. яјело, 13, 19, 128-129.

60 За Теодора је крштење залог будућих добара, односно залог Духа, о коме Павле говори (уп. 2Кор 1, 21-22), јер пуноћу благодати ћемо примити тек када уђемо у саму стварност. Оно је слика усиновљења које ћемо примити по васкрсењу, онда када будемо наново рођени (уп. Teodor Mopsuestijski, нав. gјело, 14, 6-7, 134). То је стварност коју он непрестано наглашава и истиче у својим катихезама. Зато, све то што бива у крштењу бива у знаковима и у слици, и крштење бива тумачено кроз те знакове и слике. Штавише, свака тајна указује на невидљиве и неизрециве ствари у знаковима и симболима (в. Ист̄о, 12, 2, 105). Да би истакао снагу и реалност те слике, Теодор ју је супроставља сјенци: „Sjena otkriva blizinu nekog tijela, jer nije moguće da se pojavi sjena bez tijela; ali sjena ne pokazuje tijelo koje otkriva, dok slika to ima u svojoj naravi. Kad se vidi sliku, upoznaje se onoga koji je na slici, zbog točnosti (natituta) sličnosti, ako recimo poznajemo onoga koji je na slici predstavljen; iz sjene nikad nije moguće znati kakav je onaj čiju sjenu vidimo, jer sjena nema nikakve sličnosti s predstavljanjem tijela (gušma) 
Када свуче са себе сву одјећу, ${ }^{61}$ првосвештеник му цијело тијело помазује уљем помазања, ${ }^{62}$ ријечима:

„Pomazuje se Taj, u ime Oca i Sina i Duha Svetoga.“63

А онда улази у воду, коју је првосвештеник осветио. ${ }^{64}$ Првосвештеник стојећи пружа руку, полаже је на главу крштаваног и говори:

„Krsti se Taj u ime Oca i Sina i Duha Svetoga.“65

od kojeg sjena dolazi““ (Исйо, 12, 2, 105). На основу ових слика ми исповиједамо стварности које прижељкујемо и које очекујемо: „Onim što će biti, on potvrđuje ovo što je sada; i kroz izvr-

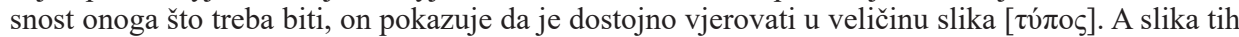
stvari jest krštenje: takvo je djelo Duha Svetoga. U nadi tih budućih (dobara) ti primaš milost krštenja; zbog njih ti pristupaš daru krštenja, tako da umreš i uskrsneš s Kristom, kako bi iznova (dmen

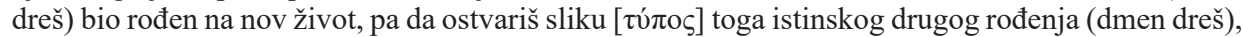
te da, privučen tim znakovima, prispiješ do udjela u (njihovim) stvarnostima" (Исӣo, 14, 6, 133 134). Нешто слично налазимо и код Кирила Јерусалимског: „Христос је истински био разапет, истински сахрањен, истински је и васкрсао; све ово дао је нама својом благодаћу да бисмо ми символом и сличношћу са његовим страдањима, самом истином остварили и задобили спасење“ (Свети Кирило Јерусалимски, нав. яјело, Тајноводствена поука 2, 5, 271-272).

61 Објашњавајући зашто су они који се крштавају наги, Златоусти вели: „Да би те подсетио на првобитну нагост, када си био у рају и ниси имао чега да се стидиш... Немој се, дакле, стидети ни овде: јер ова бања је узвишенија од раја“ (Свети Јован Златоусти, нав. gјело, XII, 11, 132).

62 Одјећа коју свлачи је знак смртности, јер ју је Адам, који раније бјеше наг, обукао пошто је сагријешио. Док је помазање читавог тијела обиљежје и знак да ће примити одјећу бесмртности у коју ће се крштењем обући (уп. Teodor Mopsuestijski, нав. gјело, 14, 8, 134135). Како вели Златоусти, пошто су се одрекли Сатане и присајединили се Христу, крштавани су прешли у Христиов йабор, гдје су постројени са осталим војницима на gуховном бојном $\bar{u} о љ y$, и сада их свештеник још наоружава тиме што их помазује миром и ставља печат крста (Свети Јован Златоусти, нав. яјело, II, 22-24, 35): „Када смо ушли у борбу, нас је [Христос] помазао, а њега [= ђавола] везао. Нас је помазао уљем радовања, а њега је везао нераскидивим ланцима, како би га ометао у борби. Ако ми се чак и догоди да се саплетем, Он ми пружа руку и помаже ми, а ако паднем, подиже ме и помаже да га опет згазим““ (Исйо, III, 9, 40).

63 Teodor Mopsuestijski, нав. яјело, 14, 130.

64 „Kao i u tjelesnom rođenju, utroba majke prima sjeme, ali božanska ruka ga oblikuje prema odredbi (donesenoj) na početku; tako i u krštenju voda postaje utroba za onoga koji se rađa, ali milost Duha oblikuje onoga koji je kršten za drugo rođenje i čini ga posve drugim" (Teodor Mopsuestijski, нав. gјело, 14, 9, 135). Нешто касније ће рећи и зашто крштење бива у води: „А razlog zašto se i stvarnosti rođenja za tebe događaju u vodi jest: jer si iz zemlje i vode bio oblikovan u početku“ (Истио, 14, 11, 137). Док свети Григорије Ниски о истоме вели: „Svako mrtvo tijelo posjeduje stanovito određeno mjesto koje odgovara njegovoj biti. Riječ je o zemlji u koju se polaže i ukapa. Ali između zemlje i vode postoji međusobna uska srodnost. Među počelima jedino su zemlja i voda teške i padaju prema dolje. Ostaju jedna u drugoj i prožimlju se. Budući da je smrt, u skladu sa zajedničkom sudbinom, Predvodnika našega života odvela pod zemlju, nasljedovanje se njegove smrti, kako mi to činimo, obavlja u počelu koje je srodno sa zemljom" (Grgur iz Nise, нав. gјело, XXXV, 5, 156). Сам Тертулијан, пак, вели о овоме следеће: „No mi, ribice (pisciculi), prema svojoj »Ribi« (Ikhthyn) Isusu Hristu, rađamo se u vodi“ (Tertulijan, нав. яјело, 1, 3, 45).

65 Teodor Mopsuestijski, нав. gјело, 14, 130. Они који улазе у царство Божије треба да буду рођени другим рођењем (уп. Истио, 14, 3, 132). Христос је у Јн 3,3 крштење назвао новим рођењем, јер оно у себи садржи слику ( крштења, учествујемо у том новом рођењу (уп. Истио, 14, 4, 132-133). Златоусти вели да је ова тајанствена свештенорадња припрема за долазак Духа Светога (уп. Свети Јован Златоу- 
Потом га трократно погружава, изговарајући појединачно имена трију лица Свете Тројице приликом сваког погружења. ${ }^{66}$ Када новокрштени изађе из воде, облачи потпуно сјајну одјећу ${ }^{67}$, а првосвештеник му опет приступа и знаменује га ${ }^{68}$ на челу, говорећи притом:

сти, нав. gјело, II, 26, 36). Наиме, када се човјек крштава, Дух Свети га ослобађа од окова Сатане, тако да он сада, у овом свијету, може усмјерити себе na način koji priliči boravljenju $i$ građanstvu neba (Teodor Mopsuestijski, нав. gjeлo, 13, 1, 120). Поред благодати потребне да се живи моралним животом, постоји промјена у стању онога који је био у оковима Сатане. Следећа два цитата указују какво је то ново стање. Најприје, Теодор има својеврсну објаву, исказ за оглашене: „Krstim se ne poradi polovičnih stvari, nego radi čudesno velikih nebeskih dobara; doista, od krštenja očekujem da i ja postanem jedan od sinova Crkve, zajednice vjernika, koji su po krštenju zadobili neizrecivo posvećenje i nadu buduće besmrtnosti i nepromjenljivosti“" (Ист̄о, $10,19,88)$. Следећи цитат се надовезује на ово: „,... onaj koji silazi »nanovo« oblikovan milošću Duha Svetoga, i »nanovo« se rađa u drugu višu ljudsku narav... To je kao neke vrste peći, na što trebaš misliti kad ulaziš u vodu, u kojoj si nanovo oblikovan tako da prelaziš u višu narav: odlažeš staru smrtnost i primaš potpuno besmrtnu i nepropadljivu narav" (Исӣo, 14, 10-11, 136-137).

Шта Теодор подразумијева када Тајнама приписује преображујуће дејство на људску природу, чинећи је узвишеном? Пошто није могао да појми постојање суштинског јединства између Творца и створења, он се супротстављао сваком покушају стриктног обожења природе вјерника. За њега, спасење је учествовати, као што Христос чини, у Божијем бесмртном и непромјенљивом животу (в. Мек Леод, нав. gјело, 258-259).

66 „Zaradi toga, kad se krstim, uranjajući svoju glavu, primam smrt našega Gospodina Krista, i želim prihvatiti njegov pokop; potom uistinu još ispovijedam uskrsnuće našega Gospodina,

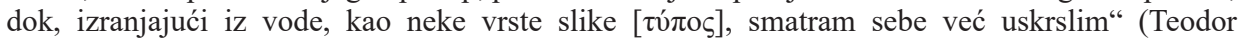
Mopsuestijski, нав. gјело, 14, 5, 133). Теодор објашњава шта означава то призивање Свете Тро-

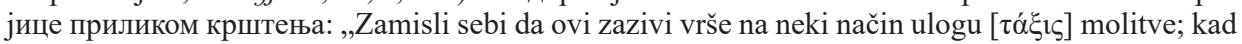
kaže: »U ime Oca«, smatraj da prvosvećenik kaže: Daruj, Oče, ta zauvijek neizreciva dobra za koja se sada ovaj krsti. A kad kaže: »I Sina«, na isti način: Udijeli, Sine, dar krsnih dobara. I kad kaže: »Duha Svetoga«: Daruj, Duše Sveti, u krštenju ono čemu je pristupio ovaj koji se krsti... Oče i Sine i Duše Sveti, daruj ovomu koji se krsti milost da se nanovo rodi“ (Ист̄о, 14, 17, 140).

67 Златоусти говори: „Из свете купељи излази нови човек уместо старога, пошто му је избрисана свака мрља греха и пошто му је свучена стара кошуља и обучена царска одежда... И као што сада вашу блиставу одежду сви добро примећују, као што сада њен сјај показује савршену чистоту ваше душе, тако и у будуће због изузетно чистог начина живота треба да будете видљиви свима, како ви који сте недавно удостојени тога дара, тако и сви они који се већ одавно наслађују том истом великодушношћу и да као светлост обасјавате све оне који вас гледају“ (Свети Јован Златоусти, нав. яјело, II, 25, 35-36 и VII, 24, 79-80). А красота тих одежди чува се непрекидном молитвом - благодарећи Богу за сва добра и молећи се да их умножавамо и сачувамо, благоразумношћу и светошћу (уп. Истио, VII, 25-32, 80-82). Златоусти упозорава новопросвијећене да ће упрљати своје сјајне одежде ако се не буду чували од гријеха, и не само новопросвијећене него и оне који су још давно примили крштење: „Могуће је, стога, да неко буде стар по годинама живота, а да буде млад и новопросвећен по благодати која је у њему у пуном цвату, а може да буде млад по годинама живота, али да је већ остарио због множине грехова“" (Ист̄о, VI, 22, 71-72).

68 Кирило Јерусалимски наглашава реалност овог светог мира којим новокрштени бива знаменован, говорећи: „Али пази! Немој ово миро којим си ти помазан да сматраш за обично. Наиме, као што хлеб у Евхаристији, након призивања Духа Светог, није више обичан хлеб, већ тело Христово, тако исто и ово миро свето није више обично миро, него дар Христа и Духа Светога, које се освећује стварним присуством његовог божанства. Њиме је достојанствено помазано твоје чело и остали удови тела. Док се тело твоје помазивало миром на видљив начин, дотле је Светим и Животворним Духом душа твоја освећивана“ (Свети Ки- 


\section{„Znamenuje se Taj u ime Oca i Sina i Duha Svetoga.“69}

Након овога, будући наново рођени ${ }^{70}$, новокрштени приступају besmrtnoj hrani, тј. Евхаристији ${ }^{71}$, коју не може јести нико ко није инициран за тајну Цркве и ко није крштен у смрт Господњу. ${ }^{72}$ Овом храном новорође-

рило Јерусалимски, нав. яјело, Тајноводствена поука $3,3,275)$. А потом објашњава зашто се врши ово знаменовање чела и осталих удова: „Најпре ти је помазано чело, да бисте се избавили од стида који је први човек - преступник пронео целим светом, али u pagu $\bar{u} о \bar{a} a$ ga бu-

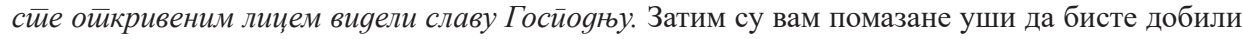
дар слушања божанских тајни; пророк Исаија каже: Госйоg ми ойвори уши gа слушам; а Господ Исус у еванђељу каже: ко има уши gа чује, нека чује. Потом ноздрве: да бисте осетивши и омирисавши божанствено миро, одговорили: Хрисӣов миомирис јесмо Боїу међу онима који се сйасавају. Затим прса: да, обукавии се у оклой йравgе можейе ояолейи лукавсиивима Ђаволским. Као што је Христос, након свога крштења и силаска Духа Светог, изашао у пустињу и победио противника, тако исто и ви, након светог Крштења и тајновитог Миропомазања, обукостие се у свеоружије Духа Светог и успротивисте се противнику; односећи победу ви кличете: све моїу у Хрисӣу који ми моћ даје“ (Ист̄о, Тајноводствена поука 3, 4, 275-276). Као што је раније истакао истинитост спасења које се остварује крштењем (уп. Истио, Тајноводствена поука 2, 7, 272), тако и сада истиче да новокрштени нису помазани обличјем, него су истински помазани Духом Светим (уп. Исйо, Тајноводствена поука 3, 6, 276).

69 Teodor Mopsuestijski, нав. яјело, 14, 130. „То je zato što je Isus izlazeći iz vode primio Duha Svetoga koji, u obličju goluba, počinu na njem; nakon toga za nj je rečeno da bje pomazan Duhom Svetim - Duh Gospodnji na meni je, rečeno je, jer me pomaza! (Lk 4,18) i Isusa iz Nazareta Bog pomaza Duhom Svetim i snagom (Dj 10, 38), da pokaže da se Duh Sveti apsolutno ne dijeli od njega; kao što na onima koje ljudi pomazuju uljem, to ulje prodire u njih i od njih se ne dijeli, - tako i ti trebaš primiti »znamenovanje« na čelu“" (Teodor Mopsuestijski, нав. gјело, 14, 27, 145). Свети Кирило Јерусалимски говори: „Пошто сте постали причасници Христови, удостојени сте да се назовете Хришћанима тј. помазанима; за вас је Бог казао: не gойичийе моје йомазанике. Помазанима постадосте кад примисте својеобразност Светог Духа: све је на вама сада образно, односно, слично, јер постадосте обличје Христа... Помазање, у ствари, јесте Дух Свети о коме и блажени Исаија, у име Божије, каже у свом пророштву: Дух Госйоgюи је на мени и

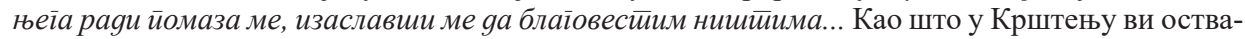
ристе подобије Христовог истинског распећа, погребења и васкрсења, тако исто и у Миропомазању. Он је помазан духовним уљем радости тј. Духом Светим који се и назива уљем радости, пошто у свему јесте виновник духовне радости: а ви сте помазани миром, поставши тиме заједничари и причасници Христови“ (Свети Кирило Јерусалимски, нав. gјело, Тајноводствена поука 3, 1-2, 274-275).

70 „Eto, po krštenju smo zadobili novo rođenje, jedno i jedincato, budući da smo po njemu ujedinjeni u jedinstvenu naravnu svezu (naqiputa). Zahvaćeni tom krsnom svezom, svi uzimamo jednu te istu hranu, u kojoj primamo isto tijelo i krv..." (Teodor Mopsuestijski, нав. gјело, 15, 40, 165).

71 А да је ова Евхаристија испуњење и циљ крштења и сам Теодор каже: „I vama dakle, koji ste u krštenju bili rođeni po milosti i dolasku Duha Svetoga, i primili ste ovo posvećenje, pripada hrana koja mu je slična, da je primite po milosti i dolasku Duha Svetoga, kako bi se učvrstilo i poraslo posvećenje koje vam je darovano i kako biste dosegnuli očekivana dobra u kojima ćemo se u budućemu svijetu naći mi u punini sveti“" (Teodor Mopsuestijski, нав. gјело, 16, 23, 179-180).

72 УП. The Constitutions of the Holy Apostles, VII, XXV, 176. Што и Јустин Мученик још неколико вијекова раније говори: „Ту храну ми називамо евхаристија (благодарење); никоме другом не дозвољавамо да учествује у њој осим ономе који верује у истину нашег учења и који се омије купањем за опроштај грехова и ново рођење, и који живи онако како нам је предао Христос“ (Јустин Мученик, Айолойија I, 65 у: Сабрана gела, 52). А још раније и писац Дияахија биљежи: „А од ваше Евхаристије (= Литургије) нека нико не једе нити пије, осим 
ни за Царство небеско храниће се као prikladnom hranom za svoje rođenje ${ }^{73}$, како и сам Теодор објашњава:

„,... jer smo svi jedincato tijelo Krista našega Gospodina, te se svi hranimo od istoga tijela i od iste krvi. Jednako kao što smo posredstvom novoga rođenja (yalda dmen dreš) i po Duhu Svetom svi postali jedno tijelo Kristovo, tako po jednoj hrani od svetih otajstava, kojom nas hrani milost Duha Svetoga, svi ulazimo u jedno zajedništvo (šautaputa) Krista našega Gospodina... kad to primamo, ostajemo u zajedništvu s Njime, budući da smo mi sami tijelo Kristovo, te po tom zajedništvu mi činimo tješnjim ono (zajedništvo) koje smo primili po novom rođenju u krstu. To je njegovo vlastito tijelo, što mi postajemo..." 74

Узимајући у обзир до сада речено, структура катихумената у овом периоду је имала следећи поредак ${ }^{75}$ :

- Трогодишња катихизација

- Четрдесетодневни пост

- Свакодневно пучавање и егзорцизми

- Испитивање оних који се спремају за просвјетљење

- Купање и строги пост оних оних који се спремају за просвјетљење

- Одрицање од сатане

- Присаједињење Христу

- Исповиједање вјере

Имајући у виду устројство катихумената претходне епохе, примјећујемо као главну карактеристику развоја катихумената актуелног периода формирање четрдесетодневног претпасхалног поста, прецизно разликовање три реда оних који се спремају за крштење, изградња крстионица у којима почињу да се врше завршне преткрштењске припреме, као и увођење крштених у име Господње..." (Дияахи - Учење Дванаесйорице Ученика, IX, 5, у: Дела айостиолских ученика, Врњци - Требиње 2005, 124). Све ово и сам Теодор наглашава у својим омилијама: „No, ne uzimaju svi ovu hranu, nego oni koji su već bili posvećeni: uzimaju je samo kršteni, koji po novom rođenju (yalda dmen dreš) primljenu u krštenju imaju prvine Duha Svetoga (Rim 8, 23) i po tome su primili posvećenje“ (Teodor Mopsuestijski, нав. gјело, 16, 22, 179).

73 Уп. Teodor Mopsuestijski, нав. gјело, 14, 29, 146. ,... jer dolikuje da mi, koji smo po smrti našega Gospodina Krista primili sakramentalno rođenje, primimo po istoj smrti sakramentalnu hranu besmrtnosti. Treba da se hranimo iz istoga odakle smo i rođeni, kao što se obično zbiva kod

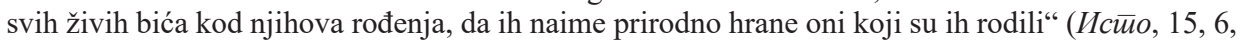
150). Свети Амросије новокрштене назива добрим орловима, који су одложили старост гријеха и примили младост благодати, те траже небо и презиру земаљско. И као добри орлови, они се и окупљају око олтара, јер гдје је тијело ту су и орлови (уп. Мт 24, 28), а жртвеник је обликом тијело и на њему је тијело Христово (в. Sveti Ambrozije, нав. gjeлo, Spis o otajstvima, IV, 2, 7, 175).

74 Teodor Mopsuestijski, нав. gјело, 16, 24, 180-181.

75 Овдје смо се користили структуром свете тајне иницијације коју је проф. Милошевић изложио у својој студији (в. Милошевић, Молишввослов, 24-29). 
формуле присаједињења коју изговарају они који се крштавају. Сем ових карактеристика које смо издвојили, јасно смо могли уочити да катихуменат у овом периоду дефинитивно достиже врхунац свог развоја и коначно доживљава своју структуралну уобличеност у свој својој пуноћи и красоти.

\section{Литература}

Апостолско предање, у: Дела айосииолских ученика, Јевтић А. (пр.), Врњци Требиње 2005, 383-409.

Афанасјев Николај, Сйуйање у Цркву, Краљево 2008.

Гаврилюк Павел, Иситория кайехизации в яревней изеркви, Москва 2001.

Дидахи - Учење Дванаесторице Ученика, у: Дела айосииолских ученика, Јевтић А. (пр.), Врњци - Требиње 2005, 119-129.

Јустин Мученик, Апологија І упућена Антонину Побожном у одбрану хришћанства, у: Свети Јустин философ и мученик, Сабрана gела, Мијатов М. (пр.), Београд - Ваљево - Србиње 2002, 11-56.

Мек Леод Фредерик, Теодор Мопсуестијски: Христолошка прожетост његовог поимања Крштења и Причешћа, у: Годишњьк, 14 (2015), 235-266.

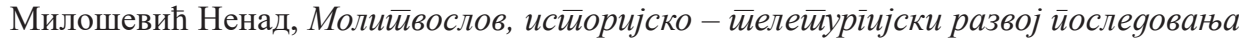
йарохијской йийика, Београд 2012.

Милошевић Ненад, У Духу и истиини, литиуриичко - канонске иееме, Београд 2011.

Нови Завјеши, САСинод СПЦ (пр.), Београд 2009.

Свети Дионисије Ареопагит, О ирквеној јерархији, Продић С. (пр.), Шибеник 2009.

Свети Јован Златоусти, Кайихезе, Акад Л. (пр.), Београд 2008.

Свети Кирило Јерусалимски, Кайихезе, Мијатов М. (пр.), Београд - Ваљево Србиње 2001.

Canones S. Hippolyti, D. B. De Haneberg (пр.), Monachii 1870.

Crnčević Ante, Inicijacijska dinamika u liturgiji krštenja od dinamike otajstva do obrednoga ustrojstva, y: Bogoslovska smotra, 79 (2009.) 3, 501-521.

Egerija, Putopis, Mandac M. (пр.), Makarska 1999.

Ferguson Everett, Preaching at Epiphany: Gregory of Nyssa and John Chrysostom on Baptism and the Church, y: Church History, Vol. 66, No. 1 (Mar. 1997), 1-17.

Folkemer Lawrence D., A Study of the Catechumenate, y: Church History, Vol. 15, No. 4 (Dec. 1946), 286-307.

Grgur iz Nise, Velika kateheza, Mandac M. (пр.), Makarska 1982.

Kvint S. F. Tertulijan, Spis o krstu, Mandac M. (пр.), Zagreb 1981.

Sveti Ambrozije, Otajstva i tajne, Mandac M. (пр.), Makarska 1986.

Sveti Avgustin, Poučavanje neupućenih, Mandac M. (пр.), Makarska 1988.

Teodor Mopsuestijski, Katehetske homilije, Tenšek T. Z. (пр.), Zagreb 2004.

Testamentum Domini nostri Jesu Christi, Ignatius Ephrem II Rahmani (пр.), Moguntiæ, sumptibus Francisci Kirchheim 1899.

The Constitutions of the Holy Apostles, Chase I. (пр.), New York - Philadelphia 1848. 
Lazar Đačić

The Church of The Holy Ascension

Subotica, Serbia

exapostilar@gmail.com

\title{
ENTERING THE CHURCH ACCORDING TO THE CATECHETICAL HOMILIES OF THEODORE OF MOPSUESTIA
}

\begin{abstract}
Summary
Perceiving Theodore's thought concerning baptism in its entirety, we get an impression that he constantly insists that, by entering the Church, we actually do enter the kingdom of God, the heavenly city, of which the Church is an image (tíros). That city, that kingdom, that life which is to come, is given to us in baptism as a pledge, an that is the reason why we are baptised. We are doing all that Christ left us with to do: we are being baptised by His baptism and do partake in His body, and all of this is done as in the

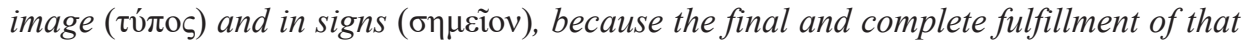
reality will be accomplished in the future, when we'll fully and unutterably taste of the grace of the Holy Spirit.
\end{abstract}

Keywords: Theodore of Mopsuestia, baptism, second birth, image ( ly dwellings, exalted city, communitarianism (šautaputa), death, ressurection, nourishment of immortality. 